\title{
De structuur van een consult - een kwalitatieve benadering Wat vinden huisartsen zelf?
}

\author{
M.E. Andeweg, M. Terluin, P.M. Boendermaker, J. Pols
}

\section{Samenvatting}

Inleiding: Aansluitend op voorafgaand onderzoek waarin met behulp van studenten gezocht werd naar de verschillen tussen het onderwijsconsult en consulten van huisartsen, werd nu de vraag gesteld: hoe betrouwbaar hebben de studenten uit het voorafgaande onderzoek de verschillen tussen onderwijs- en praktijkconsulten weergegeven? Daarnaast werd onderzocht of het consult van huisartsen onderdelen bevat die niet in het onderwijsconsult worden geleerd.

Methode: Tijdens focusgroepsessies konden huisartsen aangeven hoe hun consulten verlopen. Resultaten: Volgens huisartsen zijn de belangrijkste onderdelen van hun praktijkconsult: de hulpvraag, anamnese, het lichamelijk onderzoek en de afronding. Hun consulten kennen een losse structuur. Zo lopen anamnese en lichamelijk onderzoek door elkaar. Er worden geen andere consultonderdelen gebruikt in de praktijk dan de onderdelen die aangeleerd worden in het onderwijs.

Conclusie: De resultaten van dit onderzoek laten zien dat de gevonden verschillen in het onderzoek naar de mening van studenten betrouwbaar waren. Hiermee is de volledigheid van het onderwijsconsult opnieuw bevestigd. Meer aandacht voor het vervolgconsult en eigen stijl van de student tijdens de consultvoering is in het vaardigheidsonderwijs gewenst. (Andeweg ME, Terluin M, Boendermaker PM, Pols J. De structuur van een consult - een kwalitatieve benadering. Wat vinden huisartsen zelf? Tijdschrift voor Medisch Onderwijs 2002;21(2):57-63.)

\section{Inleiding}

Bij het vaardigheidsonderwijs van de Faculteit der Medische Wetenschappen in Groningen leren medische studenten om anamnese, lichamelijk onderzoek en gespreksvaardigheden te integreren in een consult. ${ }^{1}$ Dit onderwijsconsult bestaat uit drie fasen: vraagverheldering, anamnese/ lichamelijk onderzoek en afronding. ${ }^{2}$ Hoe de structuur van een consult er in de (huisarts)praktijk uitziet, is weinig onderzocht. De bronnen die er zijn, maken melding van een soortgelijke fasering in het consult: hulpvraag, het uitdiepen daarvan door anamnese en onderzoek, het bespreken van het behandelplan, afronding en evaluatie. ${ }^{3-6}$

In een eerdere studie onderzochten wij de verschillen tussen de structuur van het onderwijsconsult en consulten van huis- artsen. ${ }^{7}$ Hierbij beoordeelde een cohort vierdejaars studenten geneeskunde tijdens hun huisartsstage vier consulten van de huisarts. Daarbij maakten zij gebruik van een scoreformulier dat was afgeleid van het formulier dat zij bij het vaardigheidsonderwijs gebruiken om elkaar te observeren. Een onderscheid werd gemaakt tussen eerste consulten (patiënten met een nieuw probleem) en vervolgconsulten (patiënten met een al bekend probleem). Daarnaast beantwoordden de studenten open vragen over de opvallendste verschillen tussen het onderwijsconsult en het praktijkconsult, de redenen die zij voor die verschillen zagen en de mening van de huisarts hierover.

Uit dit onderzoek bleek dat alle onderdelen van het onderwijsconsult ook voorkwamen in consulten van huisartsen, 
maar dat niet alle consultonderdelen bij elk consult aan bod kwamen. Dit was het geval bij eerste consulten, maar bij vervolgconsulten ontbraken nog vaker een aantal onderdelen van het onderwijsconsult. Verder viel op dat de praktijkconsulten minder gestructureerd waren en dat anamnese en lichamelijk onderzoek door elkaar liepen. Zowel de studenten als de huisartsen noemden diverse verklaringen voor deze verschillen: De arts kent de patiënt, hij heeft minder tijd voor een consult, hij heeft ervaring, hij heeft een eigen stijl en in de praktijk gaat het vaak om vervolgconsulten. Daarnaast zijn niet alle consultonderdelen van toepassing in elk consult.

Tevens merkten de huisartsen op dat de structuur van het onderwijsconsult voor hen een hulpmiddel is bij complexe problemen. Over het wel of niet gebruiken van een samenvatting aan het begin van de afronding van een consult hadden zij tegengestelde meningen.

Een vraag die met het bovengenoemde onderzoek niet kon worden beantwoord, was of het consult van huisartsen onderdelen bevat die niet in het onderwijsconsult worden geleerd. Bovendien was niet duidelijk hoe betrouwbaar de studenten de opinies van de huisartsen over de verschillen tussen onderwijs- en praktijkconsulten hadden weergegeven. Dit leidde tot de vraagstellingen voor het huidige onderzoek: welke onderdelen horen volgens huisartsen in een consult thuis en welke laten zij aan bod komen. Worden de eerder genoemde verklaringen voor de gevonden verschillen tussen praktijkconsult en onderwijsconsult in dit onderzoek bevestigd?

\section{Methode}

Er werd besloten om met een kwalitatieve onderzoeksmethode de opvattingen over en de motieven voor de wijze van consult- voering te exploreren. ${ }^{8} 9$ De focusgroepmethode werd gekozen omdat hiermee in korte tijd veel informatie gegenereerd wordt en deze methode zeer geschikt is als er over een onderwerp nog niet veel bekend is. ${ }^{10}$ De huisartsen konden in de discussie in de focusgroep zelf aangeven hoe hun consulten (zouden moeten) verlopen en waarin deze consulten verschilden van het onderwijsconsult en de redenen daarvoor.

\section{Focusgroeponderzoek}

In een focusgroepbijeenkomst wordt door minimaal zes en maximaal twaalf deelnemers aan de hand van een aantal vragen over een onderwerp gediscussieerd onder leiding van een onafhankelijke moderator (gespreksleider). Tijdens de focusgroepbijeenkomst worden door de moderator vragen gesteld en stellingen ingebracht om de discussie te stimuleren. Er vindt een registratie plaats door middel van een bandopname en de tekst van het gesprek wordt aan de hand daarvan letterlijk uitgeschreven en vervolgens geanalyseerd. Voor focusgroeponderzoek zijn over het algemeen twee bijeenkomsten vereist. Nieuwe bijeenkomsten zijn nodig zolang er nieuwe feiten aan bod komen. Dat betekent dat van tevoren niet bekend is hoeveel focusgroepen uiteindelijk nodig zijn voor een onderzoek. ${ }^{10-12}$

In dit onderzoek werden twee focusgroepen gevormd van huisartsen die bij het medisch onderwijs betrokken zijn. De eerste groep bestond uit huisartsen die studenten hadden begeleid tijdens de eerder genoemde huisartsstage. De tweede groep bestond uit huisartsopleiders.

De volgende vragen werden door de moderator gesteld:

- Wat moet er in bijna elk consult aan de orde komen?

- Komen de genoemde onderdelen in een vaste volgorde aan de orde? 
- Als we een onderscheid maken tussen eerste consulten en vervolgconsulten, welke verschillen in het consult krijg je dan?

De volgende stellingen werden door de moderator geponeerd:

- Een samenvatting is zinloos.

- Omdat ik ervaren ben, hoef ik geen structuur in mijn consult aan te brengen.

- Rijtjes of structuur is niet nodig, de patiënt vertelt uit zichzelf wel genoeg.

- Soms is de diagnose zo duidelijk dat ik bijna niets hoef uit te vragen.

- 10 minuten is te weinig voor een volledig consult.

- Door anamnese en lichamelijk onderzoek gelijktijdig te doen, spaar ik tijd.

Iedere deelnemende huisarts heeft na afloop de samenvatting van de sessie gekregen met de vraag of hij zich kon vinden in de samenvatting.

\section{Analyse}

De analyse van de volledig uitgeschreven tekst van de focusgroepen is door twee onderzoekers onafhankelijk van elkaar verricht. De onderzoekers maakten bij de tekst aantekeningen in de kantlijn, die verkorte weergaven van de tekst waren. Een aantekening werd gemaakt wanneer de tekst relevante informatie in het kader van het onderzoek bevatte. De twee onderzoekers bespraken de op deze wijze verkregen interpretatie van de tekst om zo overeenstemming te bereiken. De aantekeningen werden vervolgens bij elkaar gebracht en geclusterd. De clusters werden ondergebracht in de thema's van de onderliggende vragen. Uiteindelijk werden de resultaten van dit focusgroeponderzoek vergeleken met de antwoorden op de open vragen uit het eerdere onderzoek.

\section{Resultaten}

In oktober en november 1998 werden de bijeenkomsten gehouden. In beide focusgroepen ontstonden levendige discussies en kwamen vele onderwerpen naar boven. Bij analyse bleek dat er tijdens de tweede focusgroepbijeenkomst geen nieuwe gezichtspunten bij gekomen waren. Het organiseren van een derde bijeenkomst was daarom niet zinvol.

Eén huisarts reageerde op de opgestuurde samenvatting. Hij vond het een goede weergave van wat er tijdens de focusgroepbijeenkomst aan bod was gekomen.

De resultaten van de focusgroepen worden hieronder belicht, onderverdeeld in vier thema's en geillustreerd met citaten.

\section{Thema 1.}

\section{Vaste onderdelen van bijna elk consult}

Een praktijkconsult moet volgens de huisartsen de volgende onderdelen bevatten: hulpvraag, anamnese, lichamelijk onderzoek, samenvatting, uitleg en een afronding van het consult.

Ik wil altijd weten wat de reden voor komst is en ik wil ook altijd een afronding hebben aan een consult.

Dat je elke keer de hulpvraag toch maar even doet bij elk consult, ook al ken je de mensen zo goed, toch maar even weer vragen, want anders tuin je er soms met open ogen in.

Misschien zou een hulpvraag al duidelijk moeten zijn voordat het consult begint. De hulpvraag valt dan buiten het bestek van het consult. Ligt hier een taak voor de doktersassistente?

Ik probeer mijn dames daar toch wel van te doordringen dat ze dat moeten gaan doen, dus dan ligt die vraagverheldering eigenlijk al bij de assistente. Ja, al eerder, het is niet altijd zo, dat dat lukt, helaas. 
Lichamelijk onderzoek is een belangrijk onderdeel in een consult. Het geeft de arts veel informatie. Maar niet iedere patiënt behoeft een lichamelijk onderzoek.

Maar niet bij elke patiënt doe je een onderzoek. Laatst kwam er een patiënt bij mij: 'Ik heb op internet gelezen dat er een bacterie in je darm kan zitten.' Ik zei 'Ja, in iedere kubieke centimeter ontlasting zitten miljarden bacteriën.', 'Ja maar die kan ook in je bloed komen.' Kijk, dan ga je geen onderzoek doen, dan leg je alleen wat uit. Dat is heel verschillend.

Ik probeer wel eens een dag zonder lichamelijk onderzoek door te komen, maar dat valt niet mee.

Een samenvatting in een consult dient om duidelijkheid te verschaffen voor patiënt en arts. Niet alle huisartsen vinden een samenvatting altijd nuttig, want sommige problemen zijn al overduidelijk.

...dat is dus een samenvatting van het verhaal, maar in ieder geval moet er iets in zitten van duidelijkheid over en weer. Meestal zeer zinvol, maar in een uitzonderingsgeval niet zo erg zinvol. Bij een mevrouw die met een duidelijk gebroken arm de praktijk binnenkomt, heeft het niet zoveel zin om dan samen te vatten, denk ik.

Een vaste plek voor een samenvatting is niet aan te geven.

Een samenvatting kun je ook op verschillende momenten doen. Je kunt inderdaad een anamnese samenvatten en naar aanleiding van je evaluatie zeggen; we vatten nog even de zaak samen. Het is gewoon een stap in de consultvoering.

Uitleg aan de patiënt over ziekte en behandeling is belangrijk, maar niet elke arts besteedt daar evenveel aandacht aan.
Dat vind ik een heel belangrijk aspect: uitleg. Uitleg aan mensen van 'Dat en dat heb ik gevonden.'

Nou, de collega's vallen erover, als ze een avond- of een weekenddienst hebben, zeggen ze, 'Ja, jouw patiënten, verdikke $z e g$, die willen alles weten.' Ik vind dat die mensen daar recht op hebben.

Aan het einde van een consult wordt een plan opgesteld.

Er zal een soort plan gemaakt moeten worden, of we zijn meteen klaar of er moet een nader onderzoek volgen, of een volgend consult of een nader gesprek of wat dan ook.

\section{Thema 2.}

Is er een vaste volgorde?

Structuur in het onderwijsconsult is belangrijk, maar wordt er in de praktijk een vaste volgorde gebruikt? De meeste artsen vertellen dat ze niet of niet altijd structuur in hun consultvoering gebruiken. Lichamelijk onderzoek en anamnese lopen bij veel huisartsen door elkaar. Een enkeling vindt juist dat die onderdelen strikt gescheiden moeten worden.

Tijdens het onderzoek praat ik ook wel over andere dingen, bijvoorbeeld gewoon voor het op het gemak stellen van de patiënt.

Voor het onderzoek moet je de hulpvraag wel duidelijk hebben, want je moet weten wat je moet onderzoeken.

Anderen vinden juist dat het lichamelijk onderzoek bij uitstek een moment is waarbij de anamnese uitgediept kan worden.

En dan kun je de tractusanamnese en even de specifieke anamnese tijdens het onderzoek nog doen.

Structuur in een consult is nodig. Vooral voor mensen die weinig ervaring hebben, 
kan structuur houvast bieden. Ervaren artsen zeggen niet altijd in staat te zijn om een gestructureerd consult te voeren, dat gaat nog wel eens rommelig. Anderen zijn van mening dat structuur in een consult geforceerd is. De natuurlijkheid van een consult wordt aangetast als de arts een vaste structuur aanhoudt. Patiënten zijn geneigd om veel verschillende problemen tegelijkertijd te vertellen. Structuur kan dan sturing in het gesprek geven.

Het probleem is dat patiënten het vaak zo ongestructureerd vertellen, van de hak op de tak gaan. En daar kun je met je vraagstelling wel leiding in geven, duidelijkheid boven tafel krijgen.

Ja, maar ik moet eerlijk zeggen dat ik nooit zo systematisch dat allemaal afwerk hoor. Dat gaat toch een beetje van te hooi en te gras.

Structuur biedt houvast voor artsen die nog niet veel ervaring hebben.

Ik vind wel dat als je minder ervaren bent, dat dan een structuur meer houvast biedt. Ik denk dat je dan minder snel de mist in zal gaan. Nou misschien geldt dat ook wel voor mensen met ervaring hoor.

Tenslotte weten huisartsen wel hoe ze een gestructureerd consult zouden moeten voeren, maar ze brengen daar niet altijd wat van terecht.

En als je nu vraagt 'Ja, en wat bak je er nu zelf van?' Ja, dan kan ik hier wel een mooi verhaal houden. Ik denk dat de enige manier om dat te constateren is, dat je mij ook een uur opneemt, want ik vind het moeilijk om van mezelf te zeggen of ik dat allemaal keurig netjes doe. Want ik herken hier echt ontzettend veel dingen. Ik denk dat ik ook dagen heb dat ik maar een beetje aanrommel en dat er ook wel eens dagen zijn dat ik wat meer bij de les blijf.

\section{Thema 3.}

Een eerste consult versus een vervolgconsult

Een vervolgconsult heeft een andere inhoud dan een eerste consult. Onderdelen die volgens huisartsen dan meer aan de orde komen zijn het beleid en evaluatie van de ingestelde behandeling. Er wordt soms dieper op de klacht ingegaan en het initiatief komt in een vervolgconsult meer bij de arts te liggen.

Je spreekt af: 'Foto, bloedonderzoek en weer terugkomen.' Je bespreekt dan uitslagen. En ik denk dat zo'n tweede consult er dan toch heel anders uitziet.

$\mathrm{Ja}$, of het is gewoon wel iets en dat jij een bepaalde behandeling hebt ingesteld en dat je nu wilt kijken hoe dat gaat. Of juist nog verder uitdiepen. Dat je zegt van, 'We hebben een aantal dingen gehad, en we kunnen dat in de tijd niet op dit moment doen, kom als $u$ wilt terug, en dan gaan we dat nog eens verder uitspitten.'

Ik denk dat het initiatief ook meer bij de dokter ligt. Je hebt gezegd dat die patiënt nog moet terugkomen.

\section{Thema 4.}

\section{Factoren die het huisartsconsult beïnvloeden}

Een aantal factoren bepaalt het verloop in een huisartsconsult, namelijk: de tijd, de patiënt en de soort klacht waarmee de patiënt komt. Deze factoren hebben invloed op de kwaliteit van een anamnese, de duur en volgorde van een consult.

De beschikbare tijd heeft invloed op het verloop van een consult en de omgang met de patiënt. Snel werken vanwege weinig tijd kan ertoe leiden dat de arts zaken over het hoofd ziet.

Het is een stukje uitstraling dat je hebt naar de patiënt natuurlijk, die voelt dondersgoed aan dat je vandaag gehaast bent en dan maak je juist fouten. Als jij gehaast bent, dan ga je sneller door iets 
heen, en dan kom je via een omweg soms weer terug bij je anamnese.

Anders moet je er een vervolg aan breien natuurlijk, dan zeg je van, 'We maken een nieuwe afspraak' maar in principe is 10 minuten genoeg.

Wanneer de huisarts de patiënt kent, zorgt dat voor een andere benadering tijdens het consult. Men denkt vaak daardoor de problemen van de patiënt te kennen, maar dat is niet altijd het geval.

'Ja, hoe is het met uw vrouw?' 'Al vijf jaar geleden overleden' Dat is ook iets. Nou precies omdat je dat ook niet allemaal meer weet, vraag het maar gewoon. Als je zegt van,'Ik ken mijn patiënten', betekent dat niet dat ik alles van ze weet, maar wel dat je ze op een bepaalde manier toch in een medisch-psychosociaal hokje drukt, en ik denk dat we daar wel wat van weten.

De klacht van de patiënt bepaalt of de huisarts eerst gaat onderzoeken of begint met de anamnese.

Als iemand met zo'n duidelijke enkeldistorsie je spreekkamer komt binnenhinkelen, die gaan bij mij direct op de bank. Er zijn ook mensen die komen gewoon iets vertellen, of die gaan eenvoudig voor informatie.

\section{Conclusie}

De focusgroepmethode bleek een voor dit onderzoek geschikte methode: veel onderwerpen zijn in korte tijd naar boven gekomen. De huisartsen bevestigen nogmaals dat de belangrijkste onderdelen van een praktijkconsult zijn: de hulpvraag, anamnese, het lichamelijk onderzoek en de afronding. De huisartsen in dit onderzoek bevestigen ook dat hun consulten een losse structuur kennen. Zo lopen anamnese en lichamelijk onderzoek bij de meeste huisartsen door elkaar.
De vraag of de huisarts ook nog andere consultonderdelen gebruikt in de praktijk dan de onderdelen die aangeleerd worden in het onderwijs, kunnen we negatief beantwoorden. Dit resultaat ondersteunt de veronderstelde volledigheid van de onderwijsconsulten.

De verklaringen voor de verschillen tussen het onderwijsconsult en het praktijkconsult van de huisartsen komen overeen met die uit het vorige onderzoek. ${ }^{7} \mathrm{Met}$ name de arts zelf, de factor tijd, de patiënt en de klacht blijken invloed te hebben op het verloop van het consult, waardoor er in de praktijk veel variatie in consulten ontstaat. Bovendien komen in de praktijk veel vervolgconsulten voor. ${ }^{7}$ Vervolgconsulten kennen een andere consultstructuur, waaraan in het onderwijs (nog) geen aandacht wordt besteed.

We kunnen dus concluderen dat de studenten in het vorige onderzoek de opinies van de huisartsen betrouwbaar hebben weergegeven.

Dé structuur van het consult van dé huisarts bestaat niet. Huisartsen ontwikkelen in de loop der jaren een eigen stijl. Deze conclusie komt overeen met wat Tielens schrijft in zijn proefschrift 'Consulten van huisartsen': naast de praktijk, de klacht en de patiënt, bepaalt vooral de huisarts zelf het verloop van het consult. ${ }^{13}$ Desondanks geven huisartsen aan een vaste structuur te gebruiken bij complexe problemen. Met name voor beginnende huisartsen vinden ze deze structuur dan ook belangrijk.

Op basis van de resultaten van het hier beschreven onderzoek zouden wij er voor willen pleiten om in het vaardigheidsonderwijs de studenten na het aanleren van een vaste structuur ook een eigen stijl te laten ontwikkelen in het consultvoeren. Het jaar voorafgaande aan de co-assistentschappen en de co-assistentschappen zelf zouden daarvoor geschikt zijn, omdat de basisstructuur dan al volledig is aange- 
leerd. Ter wille van het natuurlijk verloop van een consult zou zelfs de omgekeerde volgorde (eerst eigen stijl, daarna structuur aanleren) te verdedigen zijn!

\section{Literatuur}

1. Pols J, Aukes LC, Bootsma-de Lange AM et al. Medische Professionele Vorming in Curriculum 2000. Uitgangspunten voor het programma 1-6 (interne notitie). Groningen: Faculteit der Medische Wetenschappen; mei 1996.

2. Schouten JAM. Anamnese en advies. Nieuwe richtlijnen voor de informatieuitwisseling tussen arts en patiënt. 2e druk. Alphen aan den Rijn/ Brussel: Samson Stafleu; 1988.

3. Byrne PS, Long BE. Doctors talking to patients. A study of the verbal behaviour of general practitioners consulting their surgeries. London: H.M.S.O.; 1976.

4. Have $\mathrm{P}$ ten. Sequenties en formuleringen. Aspecten van de interactionele organisatie van huisartsspreekuurgesprekken. Dordrecht: Foris Publications; 1987.

5. White JC, Rosson C, Christensen J et al. Wrapping things up. A qualitative analysis of the closing moments of the medical visit. Patient Education and Counseling 1997;30:155-65.

6. White JC, Levinson W, Roter D. "Oh by the way..." The closing moments of the medical visit. J Gen Intern Med 1994; 9:24-8.

7. Terluin M, Andeweg ME, Boendermaker PM, Pols J. De structuur van een consult, onderwijs en praktijk. Onderzoek van de praktijk. Huisarts Wet 2000;43(13):563-5. Tijschrift voor Medisch Onderwijs 2002; 21(2):50-6.

8. Lagro-Janssen T, Terluin B. Als het verhaal telt; over kwalitatief onderzoek in de geneeskunde. Huisarts Wet 1998;41(6):271-3.
9. Wolffers I. Kwalitatieve benaderingen in het medisch onderzoek. Ned Tijdschr Geneeskd 1995;139(49):2580-3.

10. Boendermaker PM, Schippers ME, Schuling J. Men neme tien deelnemers en één moderator... Het recept voor het uitvoeren van focusgroeponderzoek. Tijdschrift voor Medisch Onderwijs 2001;20(4):147-52.

11. Morgan DL. Planning focusgroups. focusgroups kit vol. 2. Thousand Oaks: Sage; 1998.

12. Wester F. Strategieën voor kwalitatief onderzoek. Muiderberg: Coutinho; 1991.

13. Tielens VCL. Consulten van huisartsen: een onderzoek naar verschillen [proefschrift]. Nijmegen: Katholieke Universiteit Nijmegen; 1987.

\section{De auteurs:}

M.E. Andeweg, arts, als agnio verbonden aan het Refaja Ziekenhuis, Stadskanaal.

M. Terluin, arts, als agnio verbonden aan het Refaja Ziekenhuis, Stadskanaal.

P.M. Boendermaker, huisarts, Disciplinegroep Huisartsgeneeskunde, Faculteit der Medische Wetenschappen, Rijksuniversiteit Groningen.

J. Pols, arts-onderwijskundige, Onderwijsinstituut, Afdeling Onderwijsontwikkeling en Kwaliteitszorg, Faculteit der Medische Wetenschappen, Rijksuniversiteit Groningen.

\section{Correspondentieadres:}

M.E. Andeweg, p/a P.M. Boendermaker, Huisartsopleiding, Disciplinegroep Huisartsgeneeskunde, Faculteit der Medische Wetenschappen, Rijksuniversiteit Groningen, A. Deusinglaan 4, 9713 AW Groningen, p.m.boendermaker@med.rug.nl.

\section{Summary}

Introduction: In a previous study students evaluated the differences between how they are taught to manage a consultation and real consultations. They observed GP consultations and compared them to the 'educational consultation'. The present study addressed the reliability of the results of that study. It also explored whether any items occurring in consultations in general practice are missing from the educational consultation.

Methods: In focus group sessions GPs discussed a number of questions and statements about how they manage consultations.

Results: According to the GPS the most important items of the consultation are: reason for encounter, history, physical examination, and closure of the consultation. Their consultations are rather loosely structured. For instance, history and physical examination are often performed simultaneously. The consultations contained no items that are different to those of the educational consultation.

Conclusion: The results demonstrate the reliability of the students' observations in the previous study. It is confirmed that the educational consultation is quite comprehensive. It is desirable that skill training courses should focus more on follow-up consultations and students' personal consulting styles. (Andeweg ME, Terluin M, Boendermaker PM, Pols, J. The structure of the consultation: a qualitative study of GP' opinions. Dutch Journal of Medical Education 2002;21(2): 57-63.) 